\title{
Protein Phosphorylation in Nerve Terminals: Comparison of Calcium/ Calmodulin-Dependent and Calcium/Diacylglycerol-Dependent Systems
}

\author{
James K. T. Wang, S. Ivar Walaas, and Paul Greengard \\ Laboratory of Molecular and Cellular Neuroscience, The Rockefeller University, New York, New York 10021
}

Rat cerebral cortical synaptosomes that had been prelabeled with ${ }^{32} \mathrm{P}$-orthophosphate were exposed to either (1) $\mathrm{K}^{+}$depolarization which causes $\mathrm{Ca}^{2+}$ influx and hence would be expected to activate $\mathrm{Ca}^{2+}$-dependent enzymes, including $\mathrm{Ca}^{2+} /$ calmodulin-dependent and $\mathrm{Ca}^{2+} /$ diacylglycerol-dependent protein kinases ( $\mathrm{Ca} / \mathrm{CaM}$ kinases and protein kinase $C$, respectively); or (2) phorbol esters or 1-oleoyl-2-acetylglycerol (OAG), which selectively activate protein kinase C. Proteins whose state of phosphorylation was affected by these treatments could be divided into 3 classes. Class $A$ includes 5 phosphoproteins that showed rapidly increased phosphorylation by synaptosomal depolarization but not by OAG or phorbol ester. Four of these proteins, synapsins la and $\mathrm{Ib}$ and proteins IIIa and IIIb, are neuron-specific, synaptic vesicle-associated proteins known to be substrates for $\mathrm{Ca} /$ CaM kinases I and II. These phosphoproteins were rapidly dephosphorylated upon synaptosomal repolarization. Class $B$ is composed of 2 phosphoproteins that showed rapidly increased phosphorylation by either synaptosomal depolarization or treatment with phorbol ester or OAG. These 2 acidic proteins of $M, 87$ and $49 \mathrm{kDa}$ are known from in vitro studies to be specific substrates for protein kinase $\mathrm{C}$. Thermolytic peptide mapping indicated that the $87 \mathrm{kDa}$ protein in synaptosomes was phosphorylated by protein kinase $\mathbf{C}$ in situ. These 2 phosphoproteins were slowly dephosphorylated upon synaptosomal repolarization. Class $C$ comprises 4 phosphoproteins that were rapidly dephosphorylated upon synaptosomal depolarization and may be substrates for $\mathrm{Ca}^{2+}$ activated protein phosphatase(s).

These data suggest that $\mathrm{Ca}^{2+}$ influx into nerve terminals activates $\mathrm{Ca} / \mathrm{CaM}$ kinases $\mathrm{I}$ and II, protein kinase $\mathrm{C}$, and unidentified protein phosphatase(s). It seems likely that the activation of these multiple $\mathrm{Ca}^{2+}$-regulated protein phosphorylation and dephosphorylation pathways underlies pleiotropic physiological actions of $\mathrm{Ca}^{2+}$ at the nerve terminal.

Two distinct $\mathrm{Ca}^{2+}$-dependent protein kinases have recently been implicated in the regulation of neurotransmitter release. One of these, $\mathrm{Ca}^{2+} /$ calmodulin-dependent protein kinase II $(\mathrm{Ca} / \mathrm{CaM}$ kinase II), increases neurotransmitter release when injected into

\footnotetext{
Received Mar. 17, 1987; revised June 3, 1987; accepted June 18, 1987.

This work was supported by USPHS Grant MH 39237.

Correspondence should be addressed to James K. T. Wang, Laboratory of Molecular and Cellular Neuroscience, The Rockefeller University, 1230 York Ave., New York, NY 10021.

Copyright (C) 1988 Society for Neuroscience $0270-6474 / 88 / 010281-08 \$ 02.00 / 0$
}

the squid giant synapse (Llinás et al., 1985). The other is protein kinase $\mathrm{C}$, which has a similar effect when activated in several non-neuronal preparations (Knight and Baker, 1983; Tanaka et al., 1984; Wakade et al., 1985), in cultured fetal brain neurons (Zurgil and Zisapel, 1985), and in rat brain synaptosomes (Nichols et al., 1987). These enzymes presumably exert their effects on neurotransmitter release by phosphorylating specific protein substrates in the nerve terminal (Nichols et al., 1987). Previous studies have shown that $\mathrm{Ca}^{2+}$ influx into nerve terminals leads to altered phosphorylation of a variety of proteins (Krueger et al., 1977; Wu et al., 1982; Robinson and Dunkley, 1983; Robinson and Dunkley, 1985; Dunkley et al., 1986a). It is therefore important to characterize the $\mathrm{Ca}^{2+}$-dependent protein phosphorylation systems present in nerve terminals, in particular, the protein kinase $\mathrm{C}$ and $\mathrm{Ca} / \mathrm{CaM}$ kinase systems.

Our experimental approach to these studies was first to examine the overall patterns of $\mathrm{Ca}^{2+}$-dependent protein phosphorylation in nerve terminals and then to analyze the activity of particular protein kinases by monitoring the state of phosphorylation of their specific substrate proteins. We used prelabeled synaptosomes, since the radioactive ATP generated in this preparation is made only in intact nerve ending particles that contain metabolically active mitochondria (Krueger et al., 1977), thus precluding significant labeling of extrasynaptosomal proteins. The stimulation conditions used were (1) $\mathrm{K}^{+}$depolarization to induce $\mathrm{Ca}^{2+}$ influx, which would be expected to activate $\mathrm{Ca}^{2+}$ dependent enzymes, including $\mathrm{Ca} / \mathrm{CaM}$ kinases and protein kinase $C$; and (2) treatment with selective activators of protein kinase $\mathrm{C}$, namely, tumor-promoting phorbol esters (Castagna et al., 1982) and the synthetic diacylglycerol 1-oleoyl-2-acetylglycerol (OAG) (Kaibuchi et al., 1983), to identify specific synaptosomal substrates for protein kinase $C$. To monitor the activity of the $\mathrm{Ca} / \mathrm{CaM}$ kinases, we measured the state of phosphorylation of synapsin I, a neuron-specific, synaptic vesicleassociated protein (De Camilli et al., 1983a, b; Huttner et al., 1983), which is phosphorylated on distinct sites by $\mathrm{Ca} / \mathrm{CaM}$ kinases I and II (Huttner et al., 1981; Kennedy and Greengard, 1981). To monitor the activity of protein kinase C, we measured the state of phosphorylation of the $87 \mathrm{kDa}$ protein, previously shown to be a specific substrate for this kinase in lysed synaptosomes (Walaas, 1982; Wu et al., 1982) and brain homogenates (Walaas et al., 1983a, b). Our results demonstrate the $\mathrm{Ca} / \mathrm{CaM}$ kinase $\mathrm{I}, \mathrm{Ca} / \mathrm{CaM}$ kinase $\mathrm{II}$, and protein kinase $\mathrm{C}$ are all activated by $\mathrm{Ca}^{2+}$ influx into synaptosomes, each with distinct substrate specificities and temporal characteristics. A preliminary report of this study has been presented in abstract form (Wang et al., 1985). 


\section{Materials and Methods}

Phorbol esters were obtained from LC Services Corp. (Woburn, MA), A23187 and OAG from Sigma (St. Louis), Staphylococcus aureus V8 protease from Miles Laboratories (New Haven, CT), thermolysin from Calbiochem (San Diego, CA), and ${ }^{32}$ P-orthophosphate from New England Nuclear (Boston). All other reagents were of analytical grade and were obtained from standard commercial sources.

Preparation and prelabeling of synaptosomes. Male Sprague-Dawley rats were decapitated and the cerebral cortex was homogenized in 0.32 M sucrose. A crude synaptosomal fraction $\left(P_{2}\right)$ was prepared as described (Krueger et al., 1977). The final pellet was resuspended in an oxygenated Krebs-Ringer buffer containing (in $\mathrm{mM}$ ) NaCl, $132.0 ; \mathrm{MgSO}_{4}, 2.4 ; \mathrm{KCl}$, 4.8; $\mathrm{CaCl}_{2}, 1.0$; glucose, 10.0; and HEPES-NaOH, 20.0, pH 7.4. In some experiments the $\mathbf{P}_{2}$ fraction was purified over Percoll gradients as described (Dunkley et al., 1986b). Synaptosomes were prelabeled at $37^{\circ} \mathrm{C}$ for $45 \mathrm{~min}$ with $1 \mathrm{mCi} / \mathrm{ml}$ of ${ }^{32} \mathrm{P}$-orthophosphate, centrifuged at $1000 \times$ $g$ for $5 \mathrm{~min}$, and resuspended at a protein concentration of $2 \mathrm{mg} / \mathrm{ml}$. Keactions were initiated by addition of $100 \mu$ l of synaptosomes to tubes containing the appropriate drug solutions and terminated by addition of "Stop Solution" [final concentration, 3\% (wt/vol) SDS, $5 \%$ glycerol, $68 \mathrm{~mm}$ Tris $\mathrm{HCl}$, and $2 \% \beta$-mercaptoethanol] and heating in a boiling water bath for $2 \mathrm{~min}$. When synaptosomes were depolarized by high $\mathrm{KCl}$ concentrations, tonicity was maintained by decreasing the $\mathrm{NaCl}$ concentration correspondingly. For the repolarization experiments, prelabeled synaptosomes were resuspended at a protein concentration of $16 \mathrm{mg} / \mathrm{ml}$. After depolarization by $40 \mathrm{mM} \mathrm{KCl}$, the synaptosomes were diluted 8-fold into $\mathrm{KCl}$-free buffer so that the final $\mathrm{KCl}$ concentration was $5 \mathrm{~mm}$. Aliquots were then added to "Stop Solution" at the appropriate time points.

Phorbol esters were dissolved in $100 \%$ dimethylsulfoxide (DMSO) and diluted into buffer with a final solvent concentration of no more than $0.1 \%$, which by itself had no effect on protein phosphorylation (data not shown). OAG was sonicated in DMSO before use as described by Kaibuchi et al. (1983).

Polvacrylamide gel electrophoresis. One-dimensional SDS/PAGE was performed by standard techniques (Laemmli, 1970), and gels were processed as described (Walaas et al., 1983a). The 2-dimensional detergent/ urea-based gel system was used as described (Imada and Sueoka, 1980), with the first dimensional gel containing $3 \%$ acrylamide, $0.1 \%$ SDS, $0.3 \%$ Triton CF-10, and $9 \mathrm{M}$ urea, and the second dimension being a conventional SDS/PAGE slab gradient gel of $7-14 \%$ acrylamide. Twodimensional analysis by isoelectric focusing and SDS/PAGE was performed as described (O'Farrell, 1975; O'Farrell et al., 1977).

Peptide mapping of partially proteolysed phosphoproteins. SDS/PAGE was carried out as described above except that the gels were not fixed in acid prior to drying. An autoradiogram was used as a guide to cut out the protein bands of interest. These were then subjected to limited proteolysis by $10 \mu \mathrm{g} / \mathrm{sample}$ of $S$. aureus protease, the proteolytic fragments were separated on a $15 \%$ gel as described (Cleveland et al., 1977; Huttner and Greengard, 1979) and quantitated by liquid scintillation spectroscopy. This method was quantitative and eluted more than $90 \%$ of the radioactivity in the original gel pieces. Thermolysin digestion for 2-dimensional phosphopeptide fingerprinting was carried out as described (Albert et al., 1984).

Immunoprecipitation of phosphoproteins. Synaptosomes were treated as described above except that the incubation was stopped by $1 \%$ SDS followed by $2 \mathrm{~min}$ of heating in a boiling water bath. Immunoprecipitation of synapsin I and protein III, by an antiserum that recognizes both proteins (gift of J. H. Haycock and M. Browning, The Rockefeller University), and of the $87 \mathrm{kDa}$ protein, by an antiserum raised against purified rat brain $87 \mathrm{kDa}$ protein (J. K. T. Wang, K. A. Albert, and P. Greengard, unpublished results), were carried out as described (Goelz et al., 1981). The immunoprecipitated proteins were separated and analyzed by SDS/PAGE as described above.

\section{Results}

Two-dimensional gel electrophoretic analysis

In preliminary experiments, a prelabeled $\mathrm{P}_{2}$ fraction from rat cerebral cortex was exposed to phorbol esters or $50 \mathrm{mM} \mathrm{KCl}$, followed by conventional 1-dimensional SDS/PAGE. The resolution of this technique was insufficient for detailed analysis of the complicated protein phosphorylation pattcrns obscrved (not shown). We therefore utilized a 2-dimensional system developed by Imada and Sueoka (1980) to improve the resolution. This system separates SDS-solubilized proteins in a detergent/ urea-containing first-dimensional tube gel mainly according to their charge properties and hydrophobicity, followed in the second dimension by a conventional separation based on molecular mass. Examples of phosphorylation patterns so obtained with a crude synaptosomal fraction are shown in Figure 1. Purified synaptosomes prepared over Percoll gradients (fractions 4 and 5 of Dunkley et al., 1986b) provided similar results (not shown).

\section{Effect of depolarization-induced $\mathrm{Ca}^{2+}$ influx on the protein phosphorylation pattern}

$\mathrm{K}^{+}$-depolarized synaptosomes showed a complex pattern of changes in protein phosphorylation (Fig. 1). Phosphorylation of synapsin Ia and Ih (86 and $80 \mathrm{kDa}$, labeled as I in Fig. 1), proteins IIIa $(74 \mathrm{kDa})$ and IIIb $(57 \mathrm{kDa})$, and substrates at 87 , 49 , and $64 \mathrm{kDa}$, was increased. The highly basic synapsin I and the acidic $87 \mathrm{kDa}$ protein (which migrated at $83 \mathrm{kDa}$ in this gel system) were well-separated from each other. Their identities were confirmed by limited proteolysis by $S$. aureus protease, which yielded the appropriate phosphopeptide fragments of 13 and $9 \mathrm{kDa}$ for the $87 \mathrm{kDa}$ protein and 35 and $10 \mathrm{kDa}$ for synapsin I (Fig. 2) (Huttner and Greengard, 1979; Wu et al., 1982). The $49 \mathrm{kDa}$ protein, upon limited proteolysis, yielded a peptide (not shown) similar to that observed for a $47 \mathrm{kDa}$ substrate for protein kinase $\mathrm{C}$ in lysed synaptosomes (Wu et al., 1982) and is likely to be the same protein. In contrast to these increases in phosphorylation, 4 distinct proteins with higher apparent molecular masses $(99,99,135$, and $170 \mathrm{kDa})$ were consistently dephoshorylated by this treatment. All of the changes induced by depolarization were dependent on the presence of $\mathrm{Ca}^{2+}$ in the incubation buffer, and were mimicked by the $\mathrm{Ca}^{2+}$ ionophore A23187 (data not shown).

\section{Effects of phorbol ester and $O A G$ on the protein phosphorylation pattern}

To identify possible physiological substrates for protein kinase C, ${ }^{32} \mathrm{P}$-prelabeled synaptosomes were treated with $100 \mathrm{nM}$ phorbol 12,13-dibutyrate (PDBu) for $1 \mathrm{~min}$ or $100 \mu \mathrm{g} / \mathrm{ml} \mathrm{OAG}$ for $10 \mathrm{~min}$. This resulted in detectable increases in phosphorylation of only the 87 and $49 \mathrm{kDa}$ proteins (Fig. 1), i.e., the same 2 major acidic proteins that responded to $\mathrm{K}^{+}$depolarization.

When the concentration of PDBu was increased to $1 \mu \mathrm{M}$ and the incubation time extended to $20 \mathrm{~min}$, there was increased phosphorylation of additional substrates at 55,67 , and $64 \mathrm{kDa}$ (Fig. 3). One of these unidentified proteins, the weakly responsive $64 \mathrm{kDa}$ protein, was prominently phosphorylated upon $\mathrm{K}^{+}$ depolarization (see Fig. 1). Phosphorylation of these additional substrates required high PDBu concentrations and long incubation times. Quantitative analysis by peptide mapping (as in Fig. 2) also revealed that phosphorylation of the $10 \mathrm{kDa}$ peptide of synapsin I increased $28 \pm 4 \%$ (mean $\pm \mathrm{SE} ; n=5$ ) in synaptosomes treated with the high $(1 \mu \mathrm{M})$ concentration of PDBu. Small increases in phosphorylation were also observed for protein III separated on 2-dimensional gels or immunoprecipitated with specific antiserum (data not shown). In contrast, the 35 $\mathrm{kDa}$ peptide of synapsin I showed no significant increase in phosphorylation $(10 \pm 8 \%)$ in response to $\mathrm{PDBu}$.

The phosphoproteins that were affected by the various treatments, except for those that were dephosphorylated by depolarization, are summarized in Table 1 . The 2 substrates that 


\section{Control}

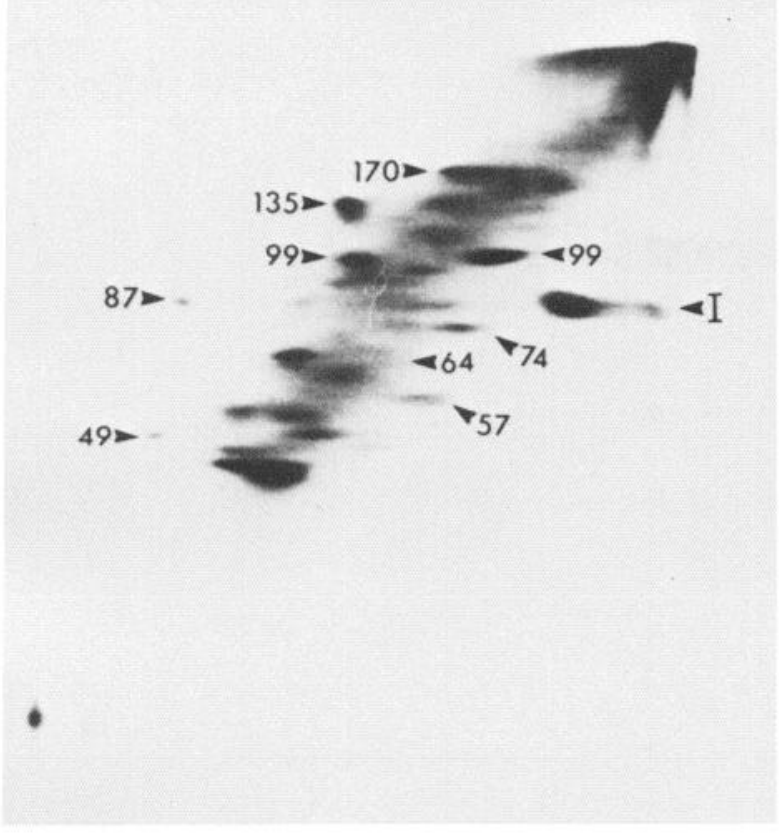

\section{PDBu}

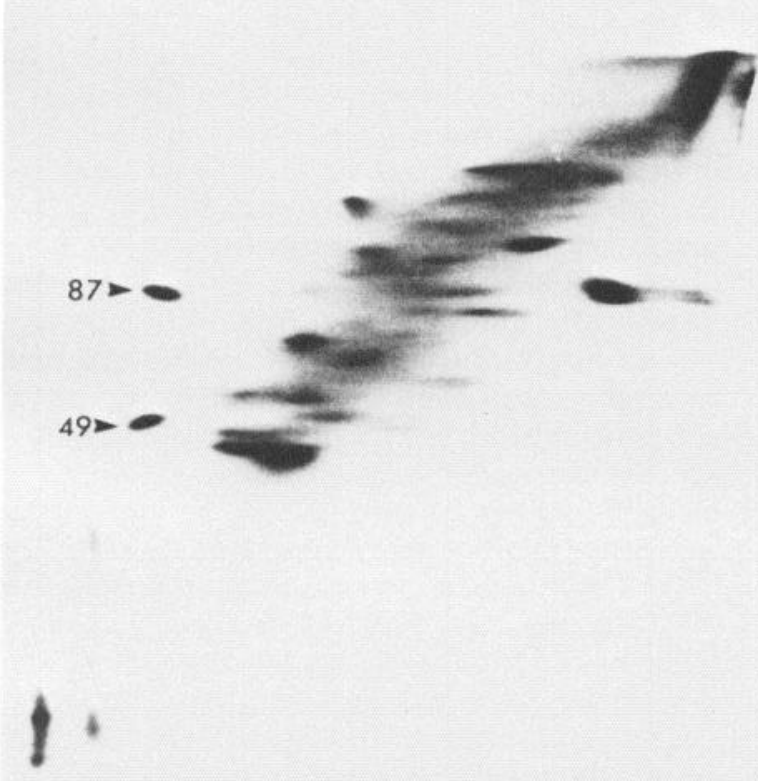

\section{$K^{+}$}

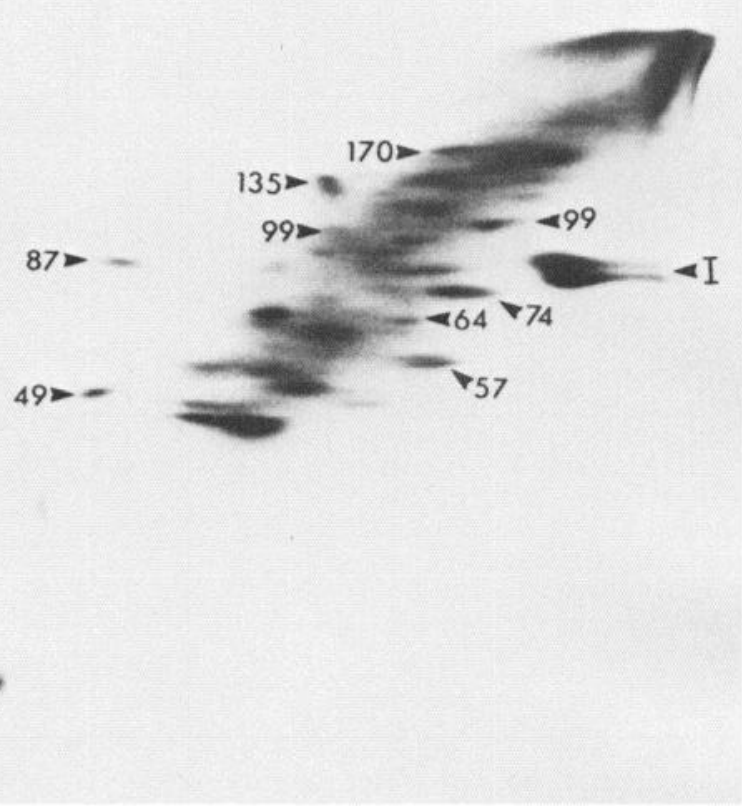

OAG

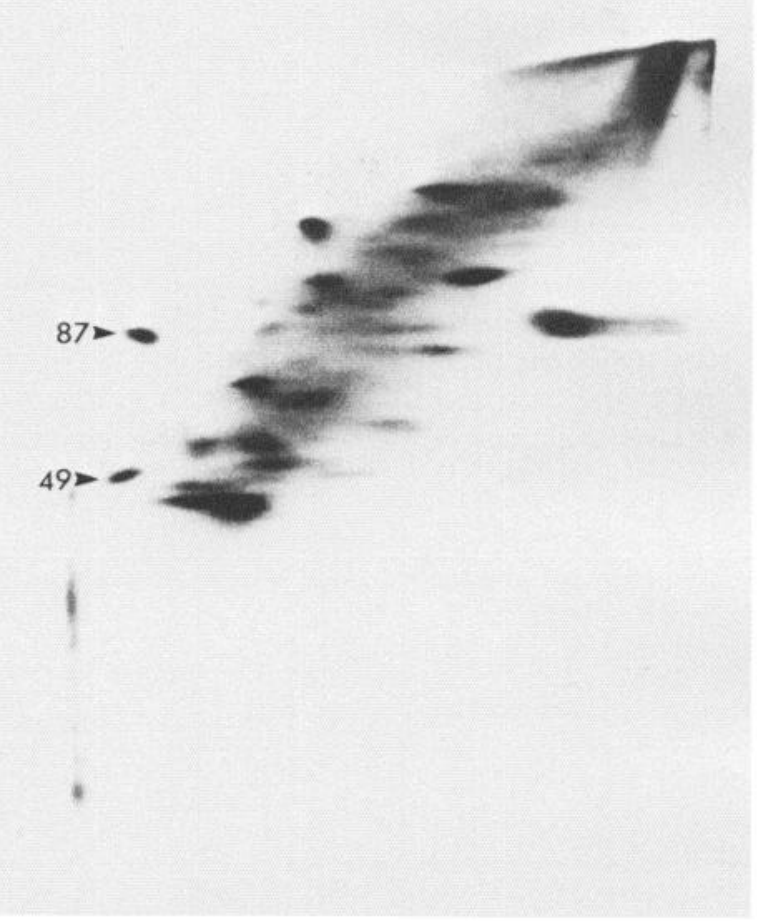

Figure 1. Two-dimensional electophoretic analysis of proteins from ${ }^{32} \mathrm{P}$-prelabeled synaptosomes. Detergent/urea-based 2-dimensional gel electrophoresis was performed as described in Materials and Methods. Arrows point to proteins that responded to the indicated treatment (KCl 50 $\mathrm{mm}, 30 \mathrm{sec}$; PDBu $100 \mathrm{~nm}, 1 \mathrm{~min}$; OAG $100 \mu \mathrm{g} / \mathrm{ml}, 10 \mathrm{~min}$ ), with the numbers denoting the $M_{\mathrm{r}}$ in $\mathrm{kDa}$. $I$, synapsin I.

responded to $\mathrm{OAG}$ and to low concentrations of $\mathrm{PDBu}$, namely, the 87 and $49 \mathrm{kDa}$ proteins, have previously been shown in vitro to be specific substrates for protein kinase $\mathrm{C}$ (Wu et al., 1982; Aloyo et al., 1983; Albert et al., 1986). Two-dimensional analysis by isoelectric focusing and SDS/PAGE (not shown) further confirmed their identity, with the $87 \mathrm{kDa}$ protein yielding multiple isoelectric spots between pI 4.0-4.6, and the 49 $\mathrm{kDa}$ protein yielding spots of pI 4.8-5.0, in agreement with 


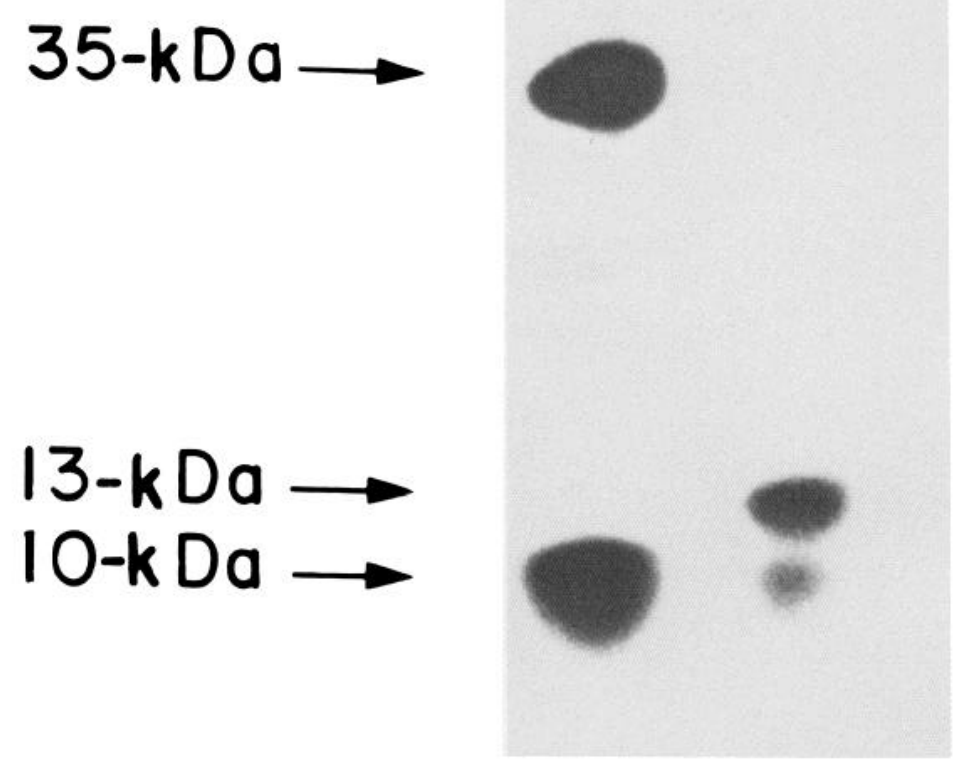

Figure 2. Limited proteolysis by $S$. aureus protease. Synapsin I (left) and the $87 \mathrm{kDa}$ protein (right) were excised from a detergent/urea-based 2-dimensional gel and subjected to limited proteolysis by $S$. aureus protease as described in Materials and Methods. An autoradiogram of the final $15 \%$ polyacrylamide gel on which the peptides were resolved is shown.

previous reports (Aloyo et al., 1983; Albert et al., 1986). Since both $\mathrm{K}^{+}$depolarization and active phorbol esters (or OAG) increased phosphorylation of these proteins, it appears that $\mathrm{Ca}^{2+}$ influx into nerve terminals activated protein kinase $\mathrm{C}$. This interpretation was further supported by thermolytic peptide fingerprinting (Albert et al., 1984) of the $87 \mathrm{kDa}$ protein from synaptosomes treated with high $\mathrm{KCl}, \mathrm{PDBu}$, or OAG. In all cases similar phosphopeptide patterns were observed (not shown), indicating that the same sites were being phosphorylated under all 3 conditions, consistent with an activation of protein kinase $\mathrm{C}$.

Quantitative analysis by limited proteolytic peptide mapping and by immunoprecipitation

To further characterize the $2 \mathrm{Ca}^{2+}$-dependent protein phosphorylation systems, we studied the activity of protein kinase $\mathrm{C}$ and the $\mathrm{Ca} / \mathrm{CaM}$ kinases in a quantitative manner. Phosphorylation of the $13 \mathrm{kDa}$ peptide derived from the $87 \mathrm{kDa}$ protein was used as a marker of protein kinase $\mathrm{C}$ activity. Phosphorylation

Table 1. $\mathrm{Ca}^{2+}$-regulated phosphorylation of proteins in synaptosomes from rat cerebral cortex

Phosphoprotein

\begin{tabular}{|c|c|c|c|c|c|}
\hline 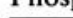 & 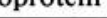 & 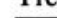 & & & \\
\hline $\mathrm{kDa}$ & Name & $\mathrm{K}^{+}$ & OAG & $\begin{array}{l}\text { PDBu } \\
\text { (low) }\end{array}$ & $\begin{array}{l}\text { PDBu } \\
\text { (high) }\end{array}$ \\
\hline
\end{tabular}

Identified proteins

$83 \quad 87 \mathrm{kDa}$

49 (B50?)

86 Synapsin Ia

80 Synapsin Ib

74 Protein IIIa

57 Protein IIIb

Unidentified proteins

$\begin{array}{llllll}55 & ? & \mathrm{NC} & \mathrm{NC} & \mathrm{NC} & \uparrow \\ 64 & ? & \Uparrow & \mathrm{NC} & \mathrm{NC} & \uparrow \\ 67 & ? & \mathrm{NC} & \mathrm{NC} & \mathrm{NC} & \uparrow\end{array}$

PDBu (low), $100 \mathrm{nM}, 1 \mathrm{~min}$; PDBu (high), $1 \mu \mathrm{M}, 20 \mathrm{~min}$. NC, no change in the state of phosphorylation. Arrows, increased state of phosphorylation, $\pi\rceil>$ $\pi>$ T. of the 10 and $35 \mathrm{kDa}$ peptides derived from synapsin I was used as a marker of the activity of $\mathrm{Ca} / \mathrm{CaM}$ kinases I and II, respectively. Following limited proteolysis of the $87 \mathrm{kDa}$ protein and synapsin I by $S$. aureus protease, the resultant phosphopeptides were quantitated (Huttner and Greengard, 1979; Wu et al., 1982). When an antiserum against the $87 \mathrm{kDa}$ protein became available during the course of these studies (J. K. T. Wang, K. A. Albert, and $\mathrm{P}$. Greengard, unpublished observations), phosphorylation of this protein was also quantitated by immunoprecipitation. The 2 procedures gave similar results (not shown).

Treatment of prelabeled synaptosomes with $50 \mathrm{~mm} \mathrm{KCl}$ for $30 \mathrm{sec}$ increased the radioactivity incorporated into the phosphopeptides derived from synapsin I and the $87 \mathrm{kDa}$ protein. The percentage increases over control (mean $\pm \mathrm{SE}, n=7$ ) were as follows: synapsin I $35 \mathrm{kDa}$ peptide, $91 \pm 15 \%$; synapsin I 10 $\mathrm{kDa}$ peptide, $35 \pm 6 \% ; 87 \mathrm{kDa}$ protein $13 \mathrm{kDa}$ peptide, $65 \pm$ $11 \%$. In contrast, treatment with $100 \mu \mathrm{g} / \mathrm{ml}$ OAG specifically increased ${ }^{32} \mathrm{P}$-incorporation into the $13 \mathrm{kDa}$ peptide from the $87 \mathrm{kDa}$ protein $(99 \pm 18 \%)$ without any effect on the 10 and $35 \mathrm{kDa}$ peptides from synapsin I, consistent with a selective stimulation of protein kinase $\mathrm{C}$.

A number of phorbol ester analogs stimulated phosphorylation of the $87 \mathrm{kDa}$ protein in a concentration-dependent manner (Fig. 4). PDBu was an effective activator and was more potent than phorbol 12,13-diacetate. Phorbol 13-acetate, a very weak tumor promoter, had only a small effect. $4 \alpha$-PDBu, and phorbol was inactive (data not shown). This rank order of potencies is consistent with the potency series for phorbol ester binding to brain membranes (Dunphy et al., 1980). The dose-response curves for the active phorbol esters were not affected by the absence of $\mathrm{Ca}^{2+}$ in the incubation medium (Fig. 4). Likewise, the effect of OAG was also independent of extracellular $\mathrm{Ca}^{2+}$ (data not shown). In contrast, $\mathrm{KCl}$-induced phosphorylation of both the $87 \mathrm{kDa}$ protein and synapsin I required extracellular $\mathrm{Ca}^{2+}$ (data not shown), in agreement with previous reports (Krueger et al., 1977; Wu et al., 1982; Robinson and Dunkley, 1983). The increase in phosphorylation of the $87 \mathrm{kDa}$ protein was significant within $1 \mathrm{~min}$ of PDBu treatment and reached a maximum by $10 \mathrm{~min}$, with the plateau maintained to at least 20 min (Fig. 5).

The time course of phosphorylation of substrates induced by 


\section{Control}

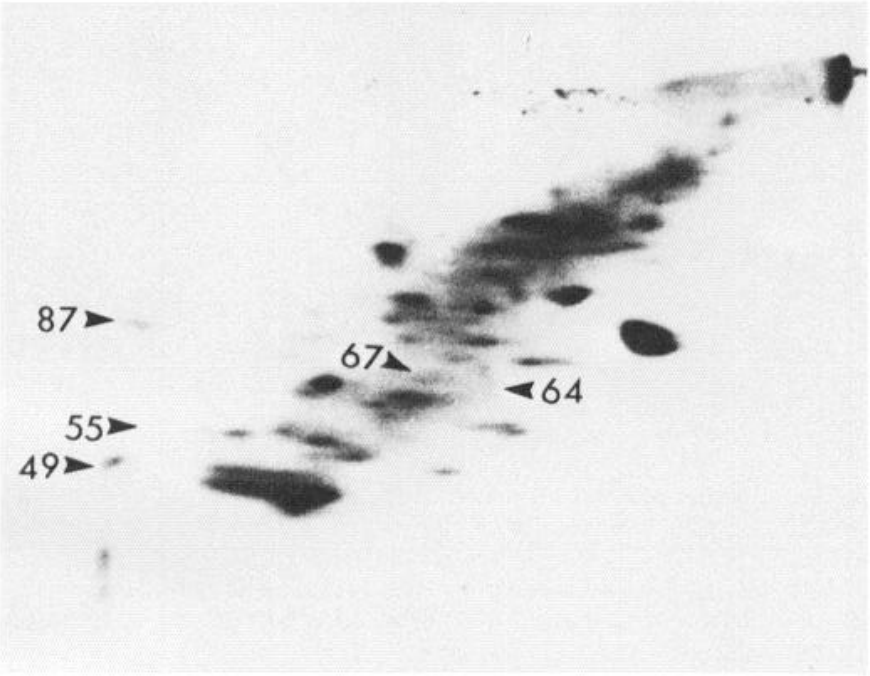

PDBu (high)

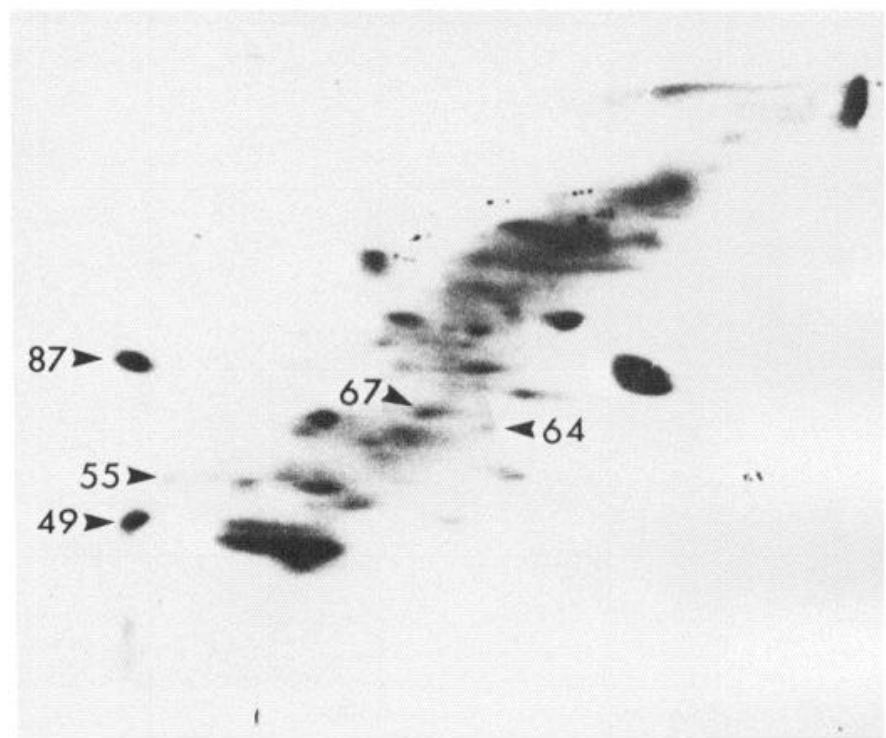

Figure 3. Effect of high concentration of PDBu on pattern of protein phosphorylation. Prelabeled synaptosomes were treated with $1 \mu \mathrm{M}$ PDBu for $20 \mathrm{~min}$. Detergent/urea-based 2-dimensional electrophoresis was then performed as described in Materials and Methods.

$\mathrm{K}^{+}$depolarization was also examined. Consistent with previous results (Krueger et al., 1977; Robinson et al., 1983), we found that the phosphorylation of synapsin I (both the 35 and the 10 kDa peptides, which showed similar time courses) increased rapidly, reaching a maximum within $10 \mathrm{sec}$. This was followed by a steady decline in phosphorylation, despite continued depolarization, such that control levels were reached within 2 min (Fig. 6). Declines in the phosphorylation of proteins IIIa and IIIb and the $64 \mathrm{kDa}$ protein were also observed in the presence of continued depolarization (data not shown). In contrast, phosphorylation of the $87 \mathrm{kDa}$ protein was rapid in onset, reaching a maximum by $15 \mathrm{sec}$, and remained elevated for at least 10 min (Fig. 6).
Repolarization of synaptosomes after a brief period of depolarization resulted in rapid reversal of the phosphorylation of synapsin I and a slow reversal of the phosphorylation of the $87 \mathrm{kDa}$ protein. Thus, when prelabeled synaptosomes were depolarized for $2 \mathrm{sec}$ (similar results were obtained after $15 \mathrm{sec}$ of depolarization), and then repolarized by dilution, the phosphorylation of synapsin I (both the 35 and $10 \mathrm{kDa}$ peptides) declined rapidly and reached basal levels by $1 \mathrm{~min}$ (Fig. 7). Repolarization also reversed the phosphorylation of the $87 \mathrm{kDa}$ protein, although it occurred at a slower rate than that of synapsin I. Phosphorylation of the $87 \mathrm{kDa}$ protein remained elevated for at least $1 \mathrm{~min}$ before a gradual decline to basal level between 3 and $5 \mathrm{~min}$.

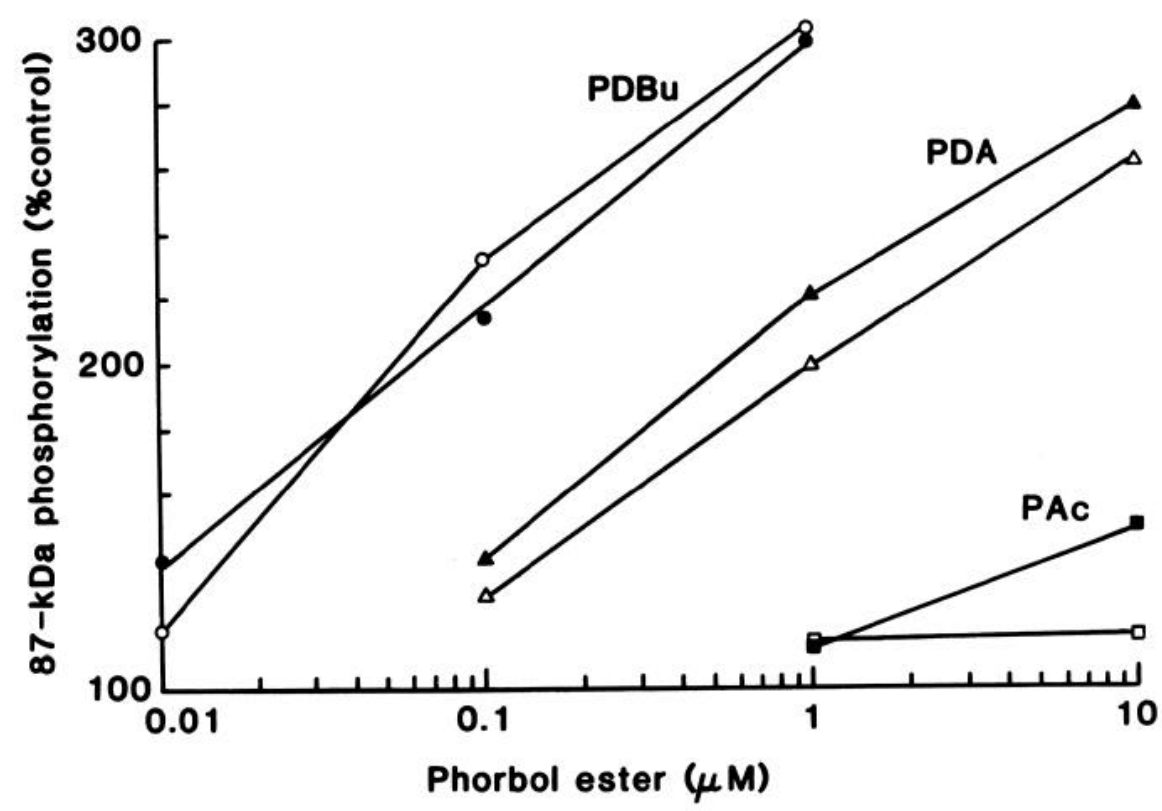

Figure 4. Concentration and $\mathrm{Ca}^{2+} \mathrm{de}-$ pendency of phorbol ester-stimulated phosphorylation of the $87 \mathrm{kDa}$ protein. Prelabeled synaptosomes were treated for $20 \mathrm{~min}$ with the indicated concentrations of phorbol esters, and ${ }^{32} \mathrm{P}$-incorporation into the $13 \mathrm{kDa}$ peptide derived from the $87 \mathrm{kDa}$ protein was quantitated by limited proteolysis by $S$. aureus protease as described in Materials and Methods. Open symbols, $1 \mathrm{~mm}$ $\mathrm{CaCl}_{2}$ in the buffer; closed symbols, 0.1 mM EGTA and no $\mathrm{CaCl}_{2}$ in the buffer. $P D B$, phorbol 12,13-dibutyrate; $P D A$, phorbol 12,13-diacetate; $P A C$, phorbol 13-acetate. 


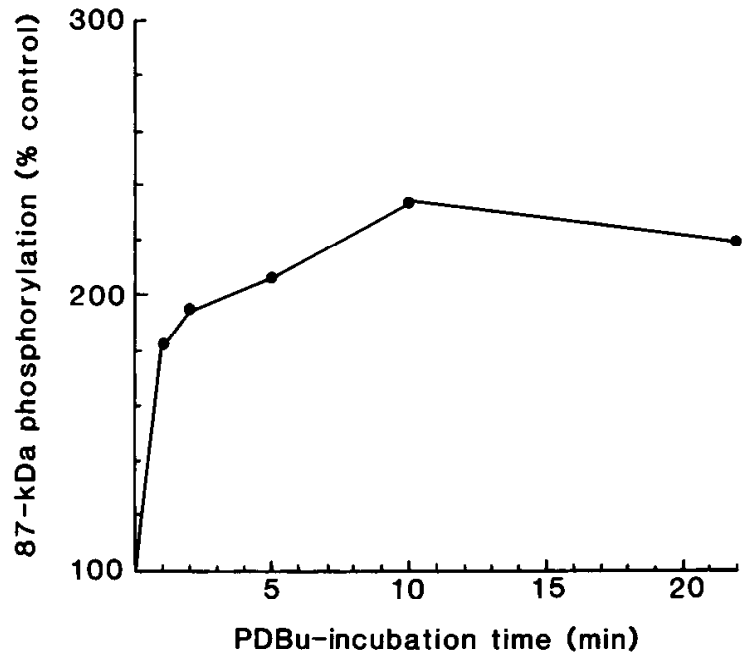

Figure 5. Time course of PDBu-stimulated phosphorylation of the 87 $\mathrm{kDa}$ protein. Prelabeled synaptosomes were exposed to $100 \mathrm{~nm} \mathrm{PDBu}$ for various periods of time. ${ }^{32} \mathrm{P}$-incorporation into the $13 \mathrm{kDa}$ peptide derived from the $87 \mathrm{kDa}$ protein was quantitated by limited proteolysis by $S$. aureus protease as described in Materials and Methods.

\section{Discussion}

In this study we have characterized 2 major $\mathrm{Ca}^{2+}$-dependent protein phosphorylation systems in nerve terminals from rat cerebral cortex. The 2 systems are independently regulated by protein kinase $\mathrm{C}$ and $\mathrm{Ca} / \mathrm{CaM}$ kinases and display distinct activation mechanisms, temporal characteristics, and subcellular localization. The phosphorylation system regulated by protein kinase $\mathrm{C}$ appears to contain a limited number of major substrates since selective activation of the kinase by PDBu (or OAG) detectably increased the phosphorylation of only the 87 and 49 $\mathrm{kDa}$ proteins. The effect of phorbol ester was time and dose dependent, with a potency series similar to that for protein kinase $\mathrm{C}$ activation. It was independent of $\mathrm{Ca}^{2+}$ in the incubation buffer, consistent with the finding that, in vitro, protein kinase

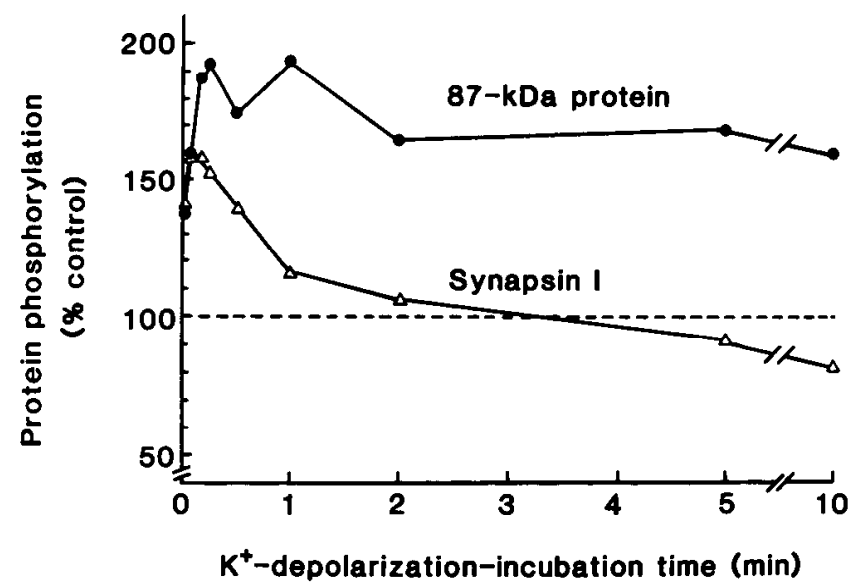

Figure 6. Time course of depolarization-induced phosphorylation of synapsin I and the $87 \mathrm{kDa}$ protein. Prelabeled synaptosomes were exposed to $40 \mathrm{~mm} \mathrm{KCl}$ for the indicated period of time. Synapsin I phosphorylation was analyzed by limited proteolysis by $S$. aureus protease as described in Materials and Methods. Radioactivity in the 35 and 10 $\mathrm{kDa}$ peptides was quantitatcd and found to follow very similar time courses; their counts were hence combined and shown here as the time course for synapsin I. The $87 \mathrm{kDa}$ protein was immunoprecipitated, and its state of phosphorylation was quantitated as described in Materials and Methods.

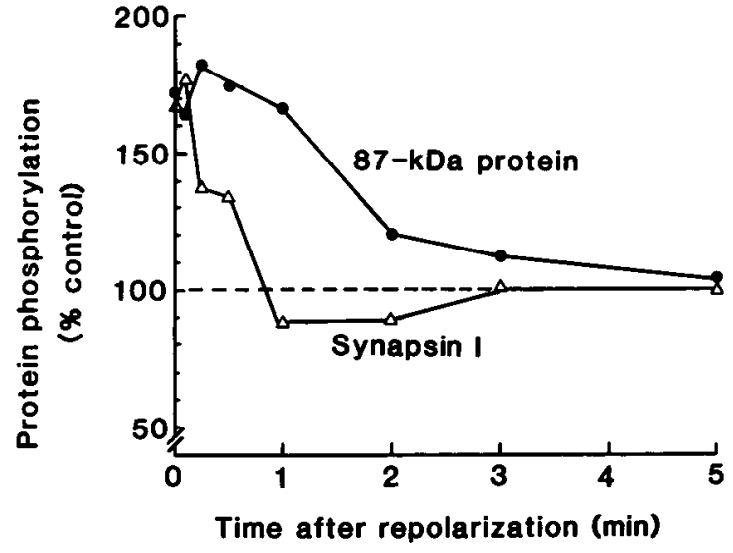

Figure 7. Time course of reversal of the phosphorylation of synapsin I and the $87 \mathrm{kDa}$ protein. Prelabeled synaptosomes were depolarized by $40 \mathrm{~mm} \mathrm{KCl}$ for $2 \mathrm{sec}$ and then repolarized by dilution as described in Materials and Methods. Aliquots were removed at various intervals. Phosphorylation of synapsin I and the $87 \mathrm{kDa}$ protein was quantitated as described in the legend to Figure 6.

C can be fully activated at low $\mathrm{Ca}^{2+}$ concentrations if diglycerides and phospholipids are both present (Kishimoto et al., 1980). The lesser potency of OAG, compared with phorbol esters, might be due to the presence of an active diacylglycerol kinase to synaptosomes (Lapetina and Hawthorne, 1971) that would rapidly metabolize OAG (Kaibuchi et al., 1983). Very high concentrations of PDBu at longer incubation times increased the state of phosphorylation of several additional proteins, including synapsin I and protein III, both of which are substrates for $\mathrm{Ca} / \mathrm{CaM}$ kinase I and cAMP-dependent protein kinase. However, these proteins are not good substrates for protein kinase $\mathrm{C}$ in vitro (A. C. Nairn, personal communication). Hence these effects of PDBu may be mediated by secondary activation of other protein kinases or phosphatases. Whether these effects are physiologically significant or arc mere artifacts of the high concentrations of phorbol esters used is presently unclear.

$\mathrm{K}^{+}$depolarization of synaptosomes altered the phosphorylation of a number of proteins, some of which have been described previously (Krueger et al., 1977; Wu et al., 1982; Robinson and Dunkley, 1983; Dunkley et al., 1986a). In particular, there was increased phosphorylation of synapsin I, protein III, and the 87 and $49 \mathrm{kDa}$ proteins. The increased phosphorylation of synapsin I occurred in both the $35 \mathrm{kDa}$ peptide, a substrate for $\mathrm{Ca} / \mathrm{CaM}$ kinase II, and the $10 \mathrm{kDa}$ peptide, a substrate for both $\mathrm{Ca} / \mathrm{CaM}$ kinase I and cAMP-dependent protein kinase (Huttner et al., 1981; Kennedy and Greengard, 1981). Protein III is likewise a substrate for $\mathrm{Ca} / \mathrm{CaM}$ kinase I and cAMPdependent protein kinase (see Nestler and Greengard, 1984; Nairn et al., 1985; Nairn and Greengard, 1987). It has been suggested that the $\mathrm{Ca}^{2+}$-induced phosphorylation of the $10 \mathrm{kDa}$ peptidc of synapsin I and of protein III in intact nerve terminals is mediated by activation of cAMP-dependent protein kinase (Dunkley et al., 1986a). However, nerve terminals contain appreciable activity of $\mathrm{Ca} / \mathrm{CaM}$ kinase I (Nairn and Greengard, 1987), which can label the $10 \mathrm{kDa}$ synapsin I peptide in lysed synaptosomes in vitro in the presence of the specific inhibitor of cAMP-dependent protein kinase (unpublished data). Hence, one could account for the changes observed in synapsin I and protein III by $\mathrm{Ca}^{2+}$ influx causing activation of $\mathrm{Ca} / \mathrm{CaM}$ kinases I and II. Upon $\mathrm{K}^{+}$depolarization, increased phosphorylation of the $87 \mathrm{kDa}$ protein occurred in the same proteolytic peptides 
that were affected by treatment with phorbol ester or OAG. Hence, $\mathrm{Ca}^{2+}$ influx also appears to activate protein kinase $\mathrm{C}$ in the nerve terminal. The 4 proteins that were dephosphorylated upon depolarization may be substrates for one or more $\mathrm{Ca}^{2+}$ dependent protein phosphatases (Shields et al., 1985). However, we cannot rule out the possibility that these 4 proteins are substrates for a highly active protein kinase that is inactivated by $\mathrm{Ca}^{2+}$ influx. In conclusion, $\mathrm{Ca}^{2+}$ influx into nerve terminals appears to activate, at the minimum, CaM kinases I and II, protein kinase $\mathrm{C}$, and possibly one or more unidentified protein phosphatases.

The 87 and $49 \mathrm{kDa}$ proteins appear to be the major substrates for protein kinase $\mathrm{C}$ in nerve terminals. Both proteins have also been identified as prominent substrates for protein kinase $\mathrm{C}$ in nerve growth cone particles (Katz et al., 1985). The $87 \mathrm{kDa}$ protein is a widely distributed brain-enriched phosphoprotein concentrated in synaptosomal membranes (Albert et al., 1986; Blackshear et al., 1986). The $49 \mathrm{kDa}$ protein is likely to be the protein called B-50 or F-1, which has been described as a neuron-specific, acidic substrate for protein kinase $\mathrm{C}$ localized to presynaptic membranes (Sorensen et al., 1981; Aloyo et al., 1983; Gispen et al., 1985; Nelson and Routtenberg, 1985). Protein kinase $\mathrm{C}$ has also been shown to be localized mainly to the particulate fraction in a brain crude mitochondrial preparation (Kikkawa et al., 1982). Thus, the kinase and its 2 major substrates in nerve terminals are enriched in the membrane fraction, suggesting that the protein kinase C-regulated system may be particularly active at synaptic membranes. This is in contrast to the $\mathrm{Ca} / \mathrm{CaM}$ kinase system, which appears to phosphorylate mainly the synaptic vesicle-associated proteins synapsins Ia and $\mathrm{Ib}$ and proteins IIIa and IIIb in presynaptic terminals.

The rapid onset and decline of synapsin I phosphorylation, whether during continued depolarization or after repolarization, is consistent with a short-term, transient role for the protein in regulating presynaptic functions. It is interesting that $\mathrm{Ca} / \mathrm{CaM}$ kinase II, when activated by $\mathrm{Ca}^{2+}$ influx, does not appear to have long-lasting effects on synapsin I phosphorylation in nerve terminals. This is in contrast to what might have been expected from the in vitro demonstration that the kinasc undergocs a $\mathrm{Ca}^{2+} /$ calmodulin-dependent autophosphorylation, resulting in an active enzyme that is no longer dependent on $\mathrm{Ca}^{2+}$ or calmodulin (Saitoh and Schwartz, 1985; Lai et al., 1986; Miller and Kennedy, 1986).

In summary, our results indicate that depolarization of the nerve terminal results in the activation of at least 2 highly regulated $\mathrm{Ca}^{2+}$-dependent protein phosphorylation systems, each with distinct substrate specificity, temporal characteristics, and subcellular localization. $\mathrm{Ca} / \mathrm{CaM}$ protein kinases, through a rapid and transient phosphorylation of synaptic vesicle-associated substrates such as synapsin I, may be involved in short-term regulation of neurotransmitter release. Protein kinase $C$, on the other hand, through a rapid but longer-lasting phosphorylation of membrane-associated proteins, may play a modulatory role at the level of the plasma membrane. Further studies of the $\mathrm{Ca}^{2+}$-dependent protein phosphorylation systems described in this report should facilitate our understanding of the mechanism of action and the physiological role of $\mathrm{Ca}^{2+}$-dependent protein kinases and their substrate proteins in nerve terminals.

\section{References}

Albert, K. A., W. C.-S. Wu, A. C. Nairn, and P. Greengard (1984) Inhibition by calmodulin of calcium/phospholipid-dependent protein phosphorylation. Proc. Natl. Acad. Sci. USA 81: 3622-3625.
Albert, K. A., S. I. Walaas, J. K.-T. Wang, and P. Greengard (1986) Widespread occurrence of " $87 \mathrm{kDa}$," a major specific substrate for protein kinase C. Proc. Natl. Acad. Sci. USA 83: 2822-2826.

Aloyo, V. J., H. Zwiers, and W. H. Gispen (1983) Phosphorylation of B-50 protein by calcium-activated, phospholipid-dependent protein kinase and B-50 protein kinase. J. Neurochem. 41: 649-653.

Blackshear, P. J., L. Wen, B. P. Glynn, and L. A. Witters (1986) Protein kinase C-stimulated phosphorylation in vitro of a $M_{r} 80,000$ protein phosphorylated in response to phorbol esters and growth factors in intact fibroblasts. J. Biol. Chem. 261: 1459-1469.

Castagna, M., Y. Takai, K. Kaibuchi, K. Sano, U. Kikkawa, and Y. Nishizuka (1982) Direct activation of calcium-activated, phospholipid-dependent protein kinase by tumor-promoting phorbol esters. J. Biol. Chem. 257: 7847-7851.

Cleveland, D. W., S. G. Fischer, M. W. Kirschner, and U. K. Laemmli (1977) Peptide mapping by limited proteolysis in sodium dodecyl sulphate and analysis by gel electrophoresis. J. Biol Chem. 232: 11021106.

De Camilli, P., R. Cameron, and P. Greengard (1983a) Synapsin I (Protein I), a nerve terminal-specific phosphoprotein. I. Its general distribution in synapses of the central and peripheral nervous system demonstrated by immunofluorescence in frozen and plastic sections. J. Cell. Biol. 96: 1337-1354.

De Camilli, P., S. M. Harris, W. B. Huttner, and P. Greengard (1983b) Synapsin I (Protein I), a nerve terminal-specific phosphoprotein. II. Its specific association with synaptic vesicles demonstrated by immunocytochemistry in agarose-embedded synaptosomes. J. Cell. Biol. 96: 1355-1373.

Dunkley, P. R., C. M. Baker, and P. J. Robinson (1986a) Depolarization-dependent protein phosphorylation in rat cortical synaptosomes: Characterization of active protein kinases by phosphopeptide analysis of substrates. J. Neurochem. 46: 1692-1703.

Dunkley, P.R., P. E. Jarvie, J. W. Heath, G. J. Kidd, and J. A. P. Rostas (1986b) A rapid method for isolation of synaptosomes on Percoll gradients. Brain Res. 372: 115-129.

Dunphy, W. G., K. B. Delclos, and P. M. Blumberg (1980) Characterization of specific binding of $\left[{ }^{3} \mathrm{H}\right]$ phorbol 12,13-dibutyrate and $\left[{ }^{3} \mathrm{H}\right]$ phorbol 12-myristate 13-acetate to mouse brain. Can. Res. 40: 3635-3641.

Gispen, W. H., J. L. M. Leunissen, A. B., Oestreicher, A. J. Verkleij, and $\mathrm{H}$. Zwiers (1985) Presynaptic localization of B-50 phosphoprotein: The (ACTH)-sensitive protein kinase substrate involved in rat brain polyphosphoinositide metabolism. Brain Res. 328: 381-385.

Goelz, S. E., E. J. Nestler, B. Chehrazi, and P. Greengard (1981) Distribution of protein I in mammalian brain as determined by a detergent-based radioimmunoassay. Proc. Natl. Acad. Sci. USA 78:21302134.

Huttner, W. B, and P. Greengard (1979) Multiple phosphorylation sites in protein I and their differential regulation by cyclic AMP and calcium. Proc. Natl. Acad. Sci. USA 76: 5402-5406.

Huttner, W. B., L. J. DeGennaro, and P. Greengard (1981) Differential phosphorylation of multiple sites in purified protein I by cyclic AMPdependent and calcium-dependent protein kinases. J. Biol. Chem. 256: $1482-1488$.

Huttner, W. B., W. Schiebler, P. Greengard, and P. De Camilli (1983) Synapsin I (Protein I), a nerve terminal-specific phosphoprotein. III. Its association with synaptic vesicles studied in a highly purified synaptic vesicle preparation. J. Cell Biol. 96: 1374-1388.

Imada, M., and N. Sueoka (1980) A two-dimensional polyacrylamide gel electrophoresis system for the analysis of mammalian cell surface proteins. Biochim. Biophys. Acta 625: 179-192.

Kaibuchi, K., Y. Takai, M. Sawamura, M. Hoshijima, T. Fujikura, and Y. Nishizuka (1983) Synergistic functions of protein phosphorylation and calcium mobilization in platelet activation. J. Biol. Chem. 258: 6701-6704.

Katz, F., L. Ellis, and K. H. Pfenninger (1985) Nerve growth cones isolated from fetal rat brain. III. Calcium-dependent protein phosphorylation. J. Neurosci. 5: 1402-1411.

Kennedy, M. B., and P. Greengard (1981) Two calcium/calmodulindependent protein kinases, which are highly concentrated in brain, phosphorylate protein I at distinct sites. Proc. Natl. Acad. Sci. USA 78: $1293-1297$.

Kikkawa, U., Y. Takai, R. Minakuchi, S. Inohara, and Y. Nishizuka (1982) Calcium-activated, phospholipid-dependent protein kinase from rat brain. Subcellular distribution, purification, and properties. J. Biol. Chem. 257: 13341-13348. 
Kishimoto, A., Y. Takai, T. Mori, U. Kikkawa, and Y. Nishizuka (1980) Activation of calcium and phospholipid-dependent protein kinase by diacylglycerol, its possible relation to phosphatidylinositol turnover. J. Biol. Chem. 255: 2273-2276.

Knight, D. E., and P. F. Baker (1983) The phorbol ester TPA increases the affinity of exocytosis for calcium in "leaky" adrenal medullary cells. FEBS Lett. 160: 98-100.

Krueger, B. K., J. Forn, and P. Greengard (1977) Depolarizationinduced phosphorylation of specific proteins, mediated by calcium ion influx, in rat brain synaptosomes. J. Biol. Chem. 252: 2764-2773.

Laemmli, U. K. (1970) Cleavage of structural proteins during the assembly of the head of bacteriophage T4. Nature 277:680-685.

Lai, Y., A. C. Nairn, and P. Greengard (1986) Autophosphorylation reversibly regulates the $\mathrm{Ca}^{2+}$ calmodulin-dependence of $\mathrm{Ca}^{2+1}$ calmodulin-dependent protein kinase II. Proc. Natl. Acad. Sci. USA 83: 4253-4257.

Lapetina, E. G., and J. N. Hawthorne (1971) The diglyceride kinase of rat cerebral cortex. Biochem. J. 122: 171-179.

Llinás, R., T. L. McGuinness, C. S. Leonard, M. Sugimori, and P. Greengard (1985) Intraterminal injection of synapsin I or calcium/ calmodulin-dependent protein kinase II alters neurotransmitter release at the squid giant synapse. Proc. Natl. Acad. Sci. USA 82: 30353039.

Miller, S. G., and M. B. Kennedy (1986) Regulation of brain type II $\mathrm{Ca}^{2+/ c a l m o d u l i n-d e p e n d e n t ~ p r o t e i n ~ k i n a s e ~ b y ~ a u t o p h o s p h o r y l a t i o n: ~}$ $\mathrm{A} \mathrm{Ca}^{2+}$-triggered molecular switch. Cell 44: 861-870.

Nairn, A. C., and P. Greengard (1987) Purification and characterization of $\mathrm{Ca}^{21} /$ calmodulin-dependent protein kinase I from bovine brain. J. Biol. Chem. 262: 7273-7281.

Nairn, A. C., H. C. Hemmings Jr., and P. Greengard (1985) Protein kinases in the brain. Annu. Rev. Biochem. 54:931-976.

Nelson, R. B., and A. Routtenberg (1985) Characterization of protein F1 $(47 \mathrm{kDa}, 4.5 \mathrm{pI}):$ A kinase $C$ substrate directly related to neural plasticity. Exp. Neurol. 89: 213-224.

Nestler, E. J., and P. Greengard (1984) Substrate proteins: Previously unknown proteins. In Protein Phosphorylation in the Nervous System, pp. 157-160, Wiley, New York.

Nichols, R. A., J. W. Haycock, J. K. T. Wang, and P. Greengard (1987) Phorbol ester enhancement of neurotransmitter release from rat brain synaptosomes. J. Neurochem. 48: 615-621.

O'Farrell, P. H. (1975) High resolution two-dimensional electrophoresis of proteins. J. Biol. Chem. 250: 4007-4021.

O'Farrell, P. Z., H. M. Goodman, and P. H. O'Farrell (1977) High resolution two-dimensional electrophoresis of basic as well as acidic proteins. Cell 12: 1133:1142.
Robinson, P. J., and P. R. Dunkley (1983) Depolarization-dependent protein phosphorylation in rat cortical synaptosomes: Factors determining the magnitude of the response. J. Neurochem. 41: 909-918.

Robinson, P. J., and P. R. Dunkley (1985) Depolarization-dependent protein phosphorylation in rat cortical synaptosomes is modulated by calcium. J. Neurochem. 44: 338-348.

Saitoh, T., and J. H. Schwartz (1985) Phosphorylation-dependent subcellular translocation of a $\mathrm{Ca}^{2+} /$ calmodulin-dependent protein kinase produces an autonomous enzyme in aplysia neurons. J. Cell Biol. 100: 835-842.

Shields, S. M., T. S. Ingebritsen, and P. T. Kelly (1985) Identification of protein phosphatase 1 in synaptic junctions: Dephosphorylation of endogenous calmodulin-dependent kinase II and synapse-enriched phosphoproteins. J. Neurosci. 12: 3414-3422.

Sorensen, R. G., L. P. Kleine, and H. R. Mahler (1981) Presynaptic localization of phosphoprotein B-50. Brain Res. Bull. 7: 57-61.

Tanaka, C., K. Taniyama, and M. Kusunoki (1984) A phorbol ester and A23187 act synergistically to release acetylcholine from the guinea pig ileum. FEBS Lett. 175: 165-169.

Wakade, A. R., R. K. Malhotra, and T. D. Wakade (1985) Phorbol ester, an activator of protein kinase $C$, enhances calcium-dependent release of sympathetic neurotransmitter. Naunyn-Schmiedebergs Arch. Pharmacol. 331: 122-124.

Walaas, S. I. (1982) Biochemical, anatomical and physiological characterization of calcium-regulated and cyclic nucleotide-regulated protein phosphorylation systems in nervous tissue. Acta Pharmacol. Toxicol. (Supp. II) 51: 7.

Walaas, S. I., A. C. Nairn, and P. Greengard (1983a) Regional distribution of calcium- and cyclic adenosine $3^{\prime}: 5^{\prime}$-monophosphate-regulated protein phosphorylation systems in mammalian brain. I. Particulate systems. J. Neurosci.. 3: 291-301.

Walaas, S. I., A. C. Nairn, and P. Greengard (1983b) Regional distribution of calcium- and cyclic adenosine $3^{\prime}: 5^{\prime}$-monophosphate-regulated protein phosphorylation systems in mammalian brain. II. Soluble systems. J. Neurosci. 3: 302-311.

Wang, J. K.-T., S. I. Walaas, and P. Greengard (1985) Characterization of phorbol ester-stimulated phosphorylation of specific proteins in rat brain synaptosomes. Soc. Neurosci. Abstr. 11:846.

Wu, W. C.-S., S. I. Walaas, A. C. Nairn, and P. Greengard (1982) Calcium/phospholipid regulates phosphorylation of a $\mathbf{M}_{r}$ " $87 \mathrm{k}$ " substrate protein in brain synaptosomes. Proc. Natl. Acad. Sci. USA 79. 5249-5253.

Zurgil, N., and N. Zisapel (1985) Phorbol ester and calcium act synergistically to enhance neurotransmitter release by brain neurons in culture. FEBS Lett. 185: 257-261. 